\author{
Case Study \\ www.ijrap.net (ISSN:2229-3566)
}

\title{
EFFECT OF KAREESHA PINDA SWEDA IN VATAKAPHAJA GRIDHRASI: A CASE STUDY
}

Gahalawat Manpreet $* 1$ and Kumar Pankaj ${ }^{2}$

${ }^{1}$ Final Year Student, Ayujyoti Ayurvedic College and Hospital, Sirsa, Haryana, India

${ }^{2}$ Assistant Professor, Department of Panchakarma, Ayujyoti Ayurvedic College and Hospital, Sirsa, Haryana, India

Received on: 21/01/20 Accepted on: 19/03/20

\author{
*Corresponding author \\ E-mail: manpreetpreeti157@gmail.com
}

DOI: 10.7897/2277-4343.110348

\begin{abstract}
Gridhrasi is a Vyadhi caused by aggravation of Vata Dosha which further divided into Vata and Vatakaphaja Gridhrasi. Generally in Ayurvedic hospital Gridhrasi is a very common disease that comes on daily basis more over Vatakaphaja Gridhrasi is not that much common. Many scholars assume Gridhrasi as Sciatica. Prevalence of Sciatica varies considerably ranging from $1.6 \%$ in general population to $43 \%$ in selected working population. In this present study a 30 years old male patient complains of severe low back ache radiating to right lower limb since two years and he was also complaining of numbness in right thigh after sitting in cross leg position since last one month. During examination his straight leg raise test, braggart test and faber test were found positive. Because of all sign and symptoms it was finally diagnosed with Vatakaphaja Gridhrasi which is correlated with Sciatica in modern science. The treatment included as Kareesha Pinda Sweda, Erandamooladi Niruhabasti and other Shamana aushadhas. After 15 days of treatment he got $80 \%$ relief in low back ache and $100 \%$ relief in morning stiffness and radiating pain. Because of Stambha and vedanayukta condition it finally correlated with Vatakaphaja Gridhrasi. So the treatment should include Vata and Kapha Shamana. The Kareesha Pinda Sweda removes the avarana or Kapha present inside the patient, whereas Erandamooladi Basti pacifies both Vata and Kapha.
\end{abstract}

Keywords: Kareesha Pinda Sweda, Gridhrasi, Rukshana therapy.

\section{INTRODUCTION}

Gridhrasi is called so due to Gridhavatagati means person suffering from this disease walk like bird Gridhra. The legs of patient become tense and slightly curved that resemble with gait of Vulture. Gridhrasi is of two types Vataja and Vatakaphaja. Vataja Gridhrasi shows symptoms like Stambha, Ruka, Toda whereas Vatakaphaja Gridhrasi shows symptoms like tandra, gourava, Arochaka, Agnimandya, Mukhapraseka, Bhaktadwesha. Due to resemblance of sign and symptoms Gridhrasi is mostly correlated with Sciatica. ${ }^{1}$

The prevalence of Sciatica varies considerably ranging from $1.6 \%$ in general population to $43 \%$ in selected working population. Less than $1 \%$ to $40 \%$ of people have sciatica at some point in time. It mostly occurs in $40 \mathrm{~s}$ to $50 \mathrm{~s}$ and men are more frequently affected than women. ${ }^{2}$ Regular walking was also found to increase incidence of Sciatica.

Gridhrasi is one amongst Vata Nanatamaja Vyadhis. So for its treatment Snehana and Swedana should be done and before Snehana Rukshana karma is indicated in Vatakaphaja conditions. ${ }^{3,4}$ So in this condition we gave Kareesha Pinda Sweda because of its Ruksha nature. So the Kareesha Pinda Sweda is a good choice of treatment.

\section{MATERIAL AND METHODS}

30 years old male patient from Jhajjar Haryana attended our OPD on 23/6/2019 with complain of severe LBA radiating to right lower limb since two years and he was also complaining of numbness in right thigh after sitting in cross leg position since last one month. 12 years back patient has gone through heart surgery for ASD fosse ovals for that injection were given in spine region and because of his sitting job whole day he got gradually pain in low back which finally radiate to right lower limb. Regular spine injection may be the cause of pain. He was admitted in our hospital for treatment. After 15 days of treatment he got $80 \%$ relief in low back ache and $100 \%$ relief in morning stiffness and radiating pain.

Study is carried out as per International conference of Harmonization-Good Clinical Practices Guidelines (ICH-GCP) or as per Declaration of Helsinki guidelines.

\section{Physical examination}

For proper and appropriate diagnosis following tests were carried out:
1. Straight Leg Raise Test
2. Collateral Straight Leg Raise Test
3. Faber Test
4. Braggart Test

Out of these tests SLR, Faber and Braggart test were found positive on right side.

\section{Investigations}

MRI revealed mild disc bulge with broad based poster central protrusion at $\mathrm{L}_{5}-\mathrm{S}_{1}$ level causing mild thecal sac and nerve root indentation with maintained bilateral neural foramina. Mild diffuse disc bulge with small poster central protrusion at $\mathrm{L}_{4}-\mathrm{L}_{5}$ level causing moderate thecal sac indentation with maintained bilateral neural foramina. On MRI finding revealed as his Kaphavata Doshas were found vitiated which were vitiating Asthi and Majja Dhatu, Srotas involved were Asthi and Majjavaha Srotas with Sanga type of Srotodushti. As per all sign and symptoms it was diagnosed as Vatakaphaja Gridhrasi. 


\section{Treatment}

Table 1: Shodhana Chikitsa

\begin{tabular}{|c|c|c|}
\hline 1. & Sarwanga Kareeshpinda ${ }^{5,6}$ & $48 \mathrm{~min}$. \\
\hline 2. & Sarwanga Bashpasweda & $15-20 \mathrm{~min}$. \\
\hline 3. & Erandamooladi Niruha Basti ${ }^{7}:$ & \\
& Honey $-80 \mathrm{ml}$ & \\
& Saindhav $-6 \mathrm{gm}$ & \\
& Sahacharadi Taila $-75 \mathrm{ml}$ & \\
& Kalka (Shatpushpa, guduchi, kustha) $-40 \mathrm{gm}$ & \\
\hline 4. & Kashaya (Erandmoola) $-350 \mathrm{ml}$ & $75 \mathrm{ml}$ \\
\hline
\end{tabular}

Table 2: Shamana Chikitsa

\begin{tabular}{|c|c|c|}
\hline 1. & $\begin{array}{c}\text { Churna } \\
\text { Ajmodadi Churna }-80 \mathrm{gm} \\
\text { Avipatikara Churna }-60 \mathrm{gm} \\
\text { Rasnaghana Satva }-10 \mathrm{gm} \\
\text { Godanti Bhasma }-10 \mathrm{gm}\end{array}$ & 3 gm BD with honey (after food) \\
\hline 2. & Maharasnadi Kwath with 8 drops of Erandataila & $15 \mathrm{ml}$ TID (before Food) \\
\hline 3. & Vatagajankusha rasa & 1 BD (after Food) \\
\hline 4. & Mahayogarajguggulu & 2 BD (after food) \\
\hline 5. & Capsule Palsinuron & 1 BD (after Food) \\
\hline
\end{tabular}

Patient was advised for Pratimarsha Nasya with Anu taila two drops in each nostril. He was also advised for Pawanmukta asana, Markata asana, Bhujanga asana, Anuloma-viloma, sawasana. During whole period of treatment patient was strictly asked to follow Pathya Ahara-vihara like diet and full rest. Avoid junk food and excessive physical work.

\section{Grading-parameters}

Table 3: Morning Stiffness

\begin{tabular}{|c|c|}
\hline 0 & No Morning Stiffness \\
\hline 1 & Morning Stiffness for 5-10 minutes \\
\hline 2 & Morning Stiffness for half hour \\
\hline 3 & Morning Stiffness for one hour ${ }^{9}$ \\
\hline
\end{tabular}

Table 4: Radiating-Pain

\begin{tabular}{|c|c|}
\hline 0 & No Radiating Pain \\
\hline 1 & Pain Radiating up to Thighs \\
\hline 2 & Pain Radiating up to Knee joint \\
\hline 3 & Pain Radiating up to Ankle joint \\
\hline 4 & Pain Radiating up to toe \\
\hline
\end{tabular}

Table 5: Lower back ache

\begin{tabular}{|c|c|}
\hline 0 & $100 \%$ relief in LBA \\
\hline 1 & $80 \%$ relief in LBA \\
\hline 2 & $60 \%$ relief in LBA \\
\hline 3 & $40 \%$ relief in LBA \\
\hline 4 & $20 \%$ relief in LBA \\
\hline 5 & No relief/ Severe pain \\
\hline
\end{tabular}

\section{RESULT AND DISCUSSION}

\section{After 15 days of treatment}

Table 6: Result and Discussion

\begin{tabular}{|c|c|c|}
\hline & Before treatment & After Treatment \\
\hline SLR & Positive on right side & Negative \\
\hline CSLR & Negative & Negative \\
\hline Braggart & Positive on right side & Negative \\
\hline Faber & Positive on right side & Negative \\
\hline LBA & 5 & 1 \\
\hline Morning Stiffness & 3 & 0 \\
\hline Radiating Pain & 4 & 0 \\
\hline
\end{tabular}


Patient was feeling much better so discharged with Shamana Aushadha for another 15 days. After second follow up there was $100 \%$ relief in all sign and symptoms.

Kareesha Pinda Sweda is Ushmasweda as per Acharya Vagbhatta whereas Acharya Charaka has mentioned this as Pinda Sweda which is used to treat Kaphavikaras. Because of Rukshaguna of Kareesha it helps in Amapachana and Kapha shaman. Twak is the sthana of Bhrajaka Pitta and by the Swedana karma Bhrajaka Pitta got stimulated which finally act to digest the Ama present in Twak. Hence Kareesha Pinda Sweda does the Amapachana and removes Aavarana of Kapha on Vata in Vatakaphaja Gridhrasi.

Erandamooladi Niruhabasti is indicated in Kaphavrita Vata whereas Anuwasna Basti is used in Kapha awastha of Vata Vyadhi along with Kapha Dosha. Mahayogarajaguggulu is tridoshahara and also act as Rasayana so help in reducing muscular pain and radiating pain. Vatagajankusa rasa contains drugs like sudhaparada, Lohabhasma, makshikabhasma, sudhagandhaka, sudhahartala, maricha, pippali etc. It helps to cure Vata disorders which mainly related with nervous system. Due to Ushna Virya drugs and ushna, laghu nature Maharasnadikwath helps to pacify Vata in body so helps in pain reduction.

Capsule Palsinuron contains Ekangveer rasa, Sootshekharrasa, Sameerpannaga rasa, Mahavatavidhwansa rasa etc. Due to these contents it pacifies Vata Dosha at moderate level. Powder combination given in this case helps in Vata reduction and balancing Pitta Dosha along with calcium supplement which act on Asthi Dhatu.

\section{CONCLUSION}

By all properties of Kareesha Pinda Sweda it acts very beneficial in Vataja and kaphajarogas especially this Vatakaphaja Gridhrasi. The general profit that we can get is to remove the awarana of Kapha on particular Dhatu.

\section{ACKNOWLEDGEMENT}

S. G. Phyto Pharma Pvt. Ltd., Kolhapur-Maharashtra, India

\section{REFERENCES}

1. Charaka, Vatavyadhichikitsaadhyay. In: Vidyotini Hindi commentary, Pandit Kashinath Shastri, Dr. Gorakhnath
Chaturvedi, Caraksamhinta Uttarardha Chikitsa sthana, reprint edition. Varanasi: Chaukhambha Bharati Academy; 2017. p. 787, 28: 55 .

2. Kika Konstantinou, Kate M. Dunn. Sciatica: Review of epidemiological studies and Prevalence estimates; 2008. Vagbhata November. Available from: https://www.researchgate.net.

3. Vagbhata, Snehavidhiadhyay. In: Vidyotini Hindi Commentary, Kaviraj Atridev Gupta, Ashtanga Hridaya, Sutra sthana, reprint edition. Varanasi: Chaukhambha Prakashan; 2019. p. 149, 16: 37.

4. Charaka, Langhanbhringhniyaadhyay. In: Vidyotini Hindi commentary, Pandit Kashinath Shastri, Dr. Gorakhnath Chaturvedi, Charaka Samhita Purvardha Sutra sthana, reprint edition. Varanasi: Chaukhambha Bharati Academy; 2015. p. 431, 22: 30

5. Vagbhata, Swedavidhiadhyay. In: Vidyotini Hindi Commentary, Kaviraj Atridev Gupta, Ashtanga Hridaya, Sutra sthana, reprint edition. Varanasi: Chaukhambha Prakashan; 2019. p. 151, 17: 6.

6. Charaka, Swedaadhyay. In: Vidyotini Hindi commentary, Pandit Kashinath Shastri, Dr. Gorakhnath Chaturvedi, Charaka Samhita Purvardha Sutra sthana, reprint edition. Varanasi: Chaukhambha Bharati Academy; 2015. p. 286, 14: 26.

7. Charaka, Bastisutriyasidhadhyay. In: Vidyotini Hindi commentary, Pandit Kashinath Shastri, Dr. Gorakhnath Chaturvedi, Charak Samhita Uttarardha Sidhisthana, reprint edition. Varanasi: Chaukhambha Bharati Academy; 2017. p. 999, 3: 38.

8. Charaka, Vatavyadhichikitsaadhyay. In: Vidyotini Hindi commentary, Pandit Kashinath Shastri, Dr. Gorakhnath Chaturvedi, Charaka Samhita Uttarardha Chikitsa sthana 2, reprint edition. Varanasi: Chaukhambha Bharati Academy; 2017. p. 802, 28: 144.

9. Sathavane G.V, Pandya D.H, Baghel M. S. Effect of Vatari Guggulu in the management of Gridhrasi. AYU serial online 2015 cited 2020 Feb.27; 36:41-5. Available from http//www.ayujournal.org/text.asp?2015/36/1/41/169019.

\section{Cite this article as:}

Gahalawat Manpreet and Kumar Pankaj. Effect of Kareesha Pinda Sweda in Vatakaphaja Gridhrasi - A Case Study. Int. J. Res. Ayurveda Pharm. 2020;11(3):4-6 http://dx.doi.org/ $\underline{10.7897 / 2277-4343.110348}$ 